\title{
Implementasi Metode Bruce Archer dan Analisis SWOT pada Redesain Logo untuk Peningkatan Promosi Kripik Tempe Mama Ghusla
}

\author{
Maharani Kusuma Dewi', Didit Suhartono², Pungkas Subarkah ${ }^{3}$ \\ Universitas Amikom Purwokerto \\ email: subarkah@amikompurwokerto.ac.id
}

\begin{abstract}
Kripik Tempe Mama Ghusla is one of the household industries in Kedunggede village of Lumbir Subdistrict that is engaged in the snack or snack sector. This logo design considers the selection of colors and typography in order to achieve the purpose of the logo for identity. Logos with shapes, colors that will later form a new perception in the community to strengthen identity also increase the promotion of Kripik Tempe Mama Ghusla which has its own characteristics that will be easily remembered by consumers or target audiences. The analysis method used is the Brucer Archer Method with SWOT Analysis (Strength, Weakness, Opportunity, and Threats) as a data analysis. The design process starts from data collection, observation, and interviews with business owner Kripik Tempe Mama Ghusla to look for some weaknesses in the product and also collect the data needed to support in doing the redesign. The result of this study was the design for the product logo as a reinforcement of the visual identity of Kripik Tempe Mama Ghusla as an increase in promotion.
\end{abstract}

\section{Keywords: Logo, Chips, Redesign, Tempe}

Abstrak: Kripik Tempe Mama Ghusla merupakan salah satu industri rumah tangga di desa Kedunggede Kecamatan Lumbir yang bergerak pada sektor makanan ringan atau camilan. Perancangan Redesain logo ini mempertimbangkan pemilihan warna juga tipografi agar dapat mencapai tujuan logo untuk identitas. Logo dengan bentuk, warna yang nantinya akan membentuk sebuah persepsi baru di masyarakat untuk menguatkan identitas juga meningkatkan promosi Kripik Tempe Mama Ghusla yang memiliki ciri tersendiri yang akan mudah diingat oleh konsumen. Metode analisis yang digunakan adalah Metode Brucer Archer dengan Analisis SWOT (Strength, Weakness, Opportunity, and Threats) sebagai analisis data. Proses perancangan dimulai dari pengumpulan data, observasi, dan wawancara dengan pemilik usaha Kripik Tempe Mama Ghusla untuk mencari beberapa kelemahan pada produk dan juga mengumpulkan data yang dibutuhkan untuk mendukung dalam melakukan Redesain. Hasil dari penelitian ini adalah desain untuk logo produk sebagai penguatan identitas visual Kripik Tempe Mama Ghusla sebagai peningkatan promosi.

Kata kunci: Logo, Keripik, Redesain, Tempe

\section{Pendahuluan}

Tempe merupakan makanan tradisional khas Indonesia yang sudah ada sejak zaman dahulu. Makanan yang berasal dari kacang kedelai ini sudah familiar dan tidak asing lagi bagi masyarakat Indonesia. Bahkan prospek tempe sendiri sudah sampai di kancah internasional menembus pasar dunia. Potensi pasar tempe dalam negeri sendiri sdah sangat luas dan besar, bahkan mengalami peningkatan di setiap tahunnya. Karena produksi daging yang masih cukup rendah dianggap menjadi salah satu faktor tingginya konsumsi tempe.
Umumnya bahan baku pembuatan tempe berupa kacang kedelai. Tapi di beberapa daerah di Indonesia ada jenis tempe yang diproduksi dengan bahan baku seperti ampas tahu, jagung, benguk, dan lainlain. Dengan produksi bahan baku tempe yang memiliki kualitas kurang baik dan masih rendah di Indonesia, menyebabkan sebagian besar bahan baku masih di impor dari negara lain.

Tempe menjadi salah satu bahan pangan dengan jumlah penggemar yang sudah tidak bisa dihitung. Salah satu olahan yang bisa dibuat dari bahan baku tempe adalah 
tempe kripik. Menurut Kamus Besar Bahasa Indonesia, tempe kripik merupakan panganan yang dibuat dari tempe diiris tipis-tipis, dicelupkan kedalam adonan tepung yang dibumbui dan kemudian digoreng kering (KBBI.Lektur.ID, 2021).

Kripik Tempe Mama Ghusla merupakan sebuah Industri Rumah Tangga yang bergerak di bidang makanan ringan atau cemilan yang berdiri sejak tahun 2020. Industri Rumah Tangga menurut BPS (Badan Pusat Statistik) merupakan kegiatan pengubahan dari barang dasar menjadi barang jadi atau setengah jadi, atau dari yang kurang nilainya menjadi barang yang lebih tinggi nilainya dengan maksud untuk dijual dengan jumlah pekerja 1-4 orang.

Dimana usaha Kripik Tempe Mama Ghusla ini masih tergolong baru merintis dan masih belum banyak tersentuh secara teknologi. Masih secara konvensional mulai dari identitas visual produk atau logo yang ada masih sangat sederhana, juga pasar yang masih belum terlalu jauh dalam menyentuh digital marketing.

Saat ini produk utama yang dipasarkan secara langsung ke konsumen juga dititipkan kepada reseller atau warung yang ada disekitar kecamatan Lumbir juga dijual diluar wilayah Kecamatan Lumbir, seperti Wangon. Dengan kemasan produk yang sederhana hanya dengan menggunakan plastik bening yang dijual dengan harga Rp5.500. Logo Kripik Tempe Mama Ghusla yang digunakan saat ini seperti pada gambar 1

Desain logo atau identitas visual Kripik Tempe Mama Ghusla masih terlihat umum dan dalam penerapan logo masih belum menunjukan kosistensi dalam media pendukung. Desain identitas visual yang menarik juga akan berpengaruh terhadap konsumen (Khairunnas, 2019).

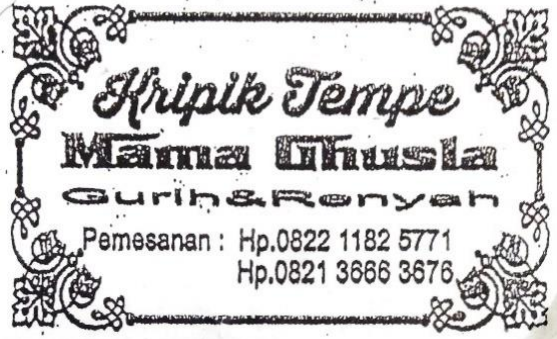

Gambar 1. Logo Kripik Tempe Mama Ghusla

Logo merupakan penampakan visual identitas yang dipergunakan untuk menggambarkan citra dan karakter suatu lembaga atau perusahaan atau organisasi yang memiliki dampak komunikasi yang besar dalam sebuah merk. Logo bisa menggunakan elemen apa saja: Logogram, ilustrasi dan lain-lain (Zuhri \& Febriyeni, 2020). jadi logo merupakan salah satu alasan utama untuk membeli suatu produk hari ini. logo sangat mempengaruhi nilai jual suatu produk(Nismawati, Ade Lose Hermanto, \& ., 2020). Logo bagian dari elemen desain sangat penting dan menjadi identitas visual. Penerapan logo selalu ada dalam aplikasi identitas visual lainnya (Wahmuda \& Hidayat, 2020).

Desain merupakan perencanaan dan perancangan yang digunakan untuk membuat suatu benda, baik dari sisi tampilan maupun fungsinya. Desain juga dapat berarti benda atau gambar atau grafis hasil dari kegiatan desain itu sendiri. Desain juga dapat diartikan sebagai benda atau gambar yang dihasilkannya sendiri, bukan hanya prosesnya. Desain memiliki beberapa cabang ilmu salah satunya adalah Desain Grafis (Thabroni, 2019). Karena Desain yang menarik berpengaruh terhadap minat beli customers atau pelanggan (Setiawan \& Putro, 2021).

Dari observasi yang telah dilakukan, permasalahan yang terdapat pada usaha Kripik Tempe Mama Ghusla adalah masih belum terlaksanakan branding dengan baik, 
baik dari sisi kurangnya kreatifitas yang dimiliki oleh pemilik usaha dalam bidang desain terhadap identitas visual atau logo produk yang ada ataupun dari sisi promosi atau penjualan secara digital.

Perlu dilakukan branding untuk meningkatkan promosi produk Kripik Tempe Mama Ghusla. Maka Solusi yang ditawarkan oleh penulis adalah dengan Redesain logo produk yang baru dari logo yang sebelumnya yang ditingkatkan dalam kualitas desainnya sebagai penguatan identitas visual untuk peningkatan dalam proses promosi.

Berdasarkan latar belakang yang telah dijabarkan penulis tertarik untuk Redesain logo Dengan output hasil dari penelitian ini adalah berupa perancangan ulang media informasi atau logo yang dapat menjadi sebagai alat bantu dalam peningkatan promosi agar branding Kripik Tempe Mama Ghusla menjadi lebih baik lagi dengan media pendukung yang digunakan adalah poster untuk konten promosi di media sosial.

\section{Metode}

Konsep penelitian sangat diperlukan dalam proses penelitian ini, khususnya dalam pembuatan Redesain Logo Kripik Tempe Mama Ghusla. Dengan tahapannya ada pada gambar 2.

1. Observasi dapat dilakukan sebelum atau sesudah pengumpulan data melalui wawancara yang bertujuan untuk mendapatan sebuah gambaran tepat mengenai objek penelitian yang berkaitan. Dari observasi yang dilakukan didapatkan gambaran jelas tentang proses produksi dan identitas visual yang digunakan pada usaha kripik tempe mama Ghusla.

2. Wawancara digunakan untuk mengetahui informasi yang berguna untuk mencari dan menentukan permasalahan dari apa yang diteliti dan mengetahui lebih banyak dari narasumber. Peneliti melakukan wawancara terkait dengan branding dari usaha yang terkait.

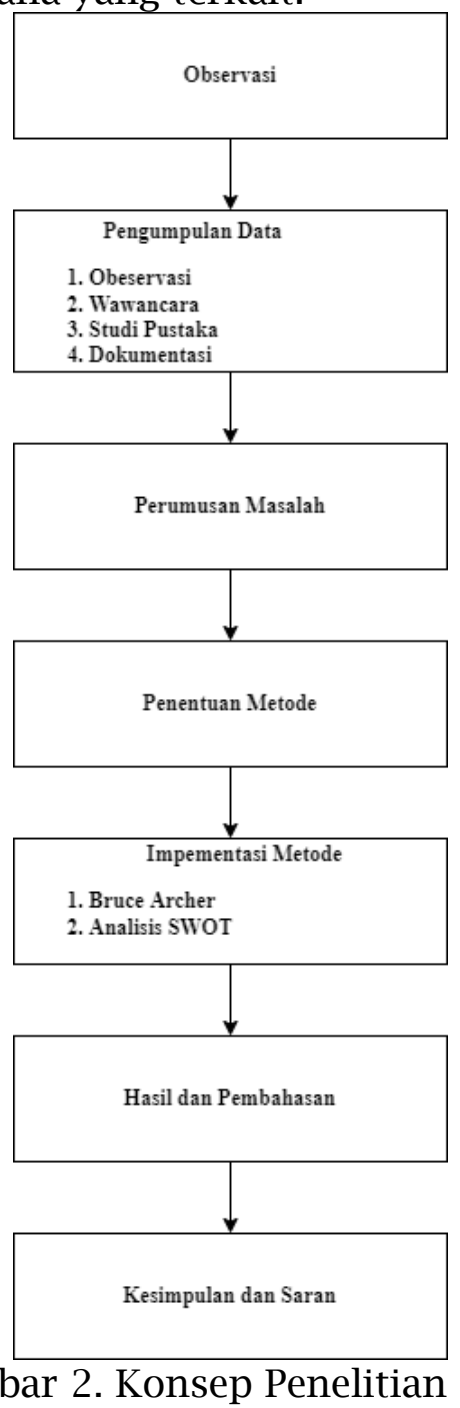

3. Studi kepustakaan merupakan Teknik pengumpulan data dengan menggunakan berbagai literatur seperti buku, majalah, jurnal dan laporan penelitian sebelumnya serta lainnya.

4. Dokumentasi merupakan Teknik dari pengumpulan data yang menggunakan dokumen yang ada pada informan relevan pada objek penelitian. Dokumentasi pada studi ini berupa gambar atau foto. 
Prosedur dalam Redesain logo ini menggunakan metode desain Bruce Archer yang terbagi menjadi tiga fase yaitu: Analisis, Kreatif, dan Eksekutif. Ketiga tahapan menguraikan beberapa langkah utama yaitu pemrograman, pengumpulan data, analisis, sintesis, pengembangan dan komunikasi.

\section{Fase Analisis}

Pada fase ini dari mana informasi dikumpulkan, diorganisasikan dan dievaluasi, faktorfaktor pengkondisian didefinisikan dan hierarki terstruktur, mendeteksi masalah, memprogram dan memperoleh informasi. Pada tahapan ini bertujuan untuk menentukan masalah. Masalah yang dapat diperoleh adalah kurangnya kreatifitas dan kurang menariknya desain dari logo produk Kripik Tempe Mama Ghusla. Selanjutnya dilakukan pendataan untuk mendukung perancangan logo. Pada tahap analisis ini, hasil dari data yang diperoleh kemudian disortir untuk kemudian dicari tautan dan maknanya.

\section{Fase Kreatif}

Fase dimana proses analisis, sintesis dan pengembangan kreatif diterapkan. Perancangan berlanjut ke tahap sintesis yang menggabungkan hasil dari analisis menjadi satu kesimpulan. Hasil sintesis digunakan untuk menyusun isi berserta makna dari logo yang dibuat. Pada tahap pengembangan, dibuat prototipe dari desain logo yang akan dibuat.

\section{Fase Eksekutif}

Fase ini merupakan apresiasi kritis dari fase yang sebelumnya dikembangkan, ide-ide disesuaikan dan proses desain dan proses interaktif dikembangkan, didefinisikan dalam proposal dan solusi. Komunikasi juga menjadi bagian dari tujuan yang melekat pada perkembangan hasilnya. Untuk tahap komunikasi dipilih media yang sesuai untuk mengkomunikasikan hasil dari desain, yang dalam hal ini adalah logo. Logo ini yang mana akan menjadi sumber informasi dan atau sebagai media informasi untuk melakukan promosi produk yang bisa dilakukan melalui media sosial.

Pada penelitian ini Analisis SWOT digunakan sebagai analisis dari data yang dikumpulkan oleh peneliti. Dalam analisis SWOT perlu ditentukan tujuan penggunaannya, yaitu: hasilnya akan digunakan untuk apa. Analsis SWOT dapat digunakan sebagai dasar untuk medefinisikan visi, sebagai untuk menentukan tujuan strategis, sebagai dasar untuk generasi pertama dan alternatif strategis, untuk mengidentifikasi area kritis (Namugenyi, Nimmagadda, \& Reiners, 2019).

Menurut (Y., 2020) disebutkan bahwa analisis data SWOT dipergunakan untuk menilai dan menilai ulang yang telah ada atau telah diputuskan sebelumnya, dengan tujuan untuk mengurangi risiko yang mungkin saja terjadi. Mengoptimalkan dari segi positif yang mendukung dan menimalisir dari sisi negatif yang akan berpotensi dalam menghambat putusan perancangan yang telah diambil.

Dari digunakannya analisis SWOT ini dapat menimalisir ancaman dan kemungkinan buruk yang akan terjadi dan dapat digunakan sebagai bahan kaji usaha kripik tempe mama ghusla untuk berkembang lebih baik lagi kedepannya.

\section{Hasil}

Dari hasil pengumpulan data yang telah dilakukan terdapat beberapa faktor yang menjadi kendala pada Industri Rumah Tangga Mama Ghusla. Faktor internal yang didapatkan dari hasil wawancara dan observasi terhadap pemilik dari usaha Kripik Tempe Mama Ghusla. Kualitas dari produk yang dihasilkan sudah cukup diminati oleh konsumen. Rasa 
yang dihasilkan dari kripik tempe Mama Ghusla memiliki kerenyahan yang berbeda dibandingkan dengan produk lainnya yang sejenis. Dengan percobaan membiarkan produk selama satu bulan untuk diketahui bagaimana produk memiliki perubahan yang sigfinikan terhadap elemennya. Dihasilkan kesimpulan bahwa walaupun produk sudah melibihi satu bulan lamanya kripik tempe Mama Ghusla tetap enak dan gurih juga tidak pahit.

Dalam hal pemasaran masih belum menunjukan peningkatan yang signifikan. Dari hasil wawancara yang dilakukan, dalam hal identitas produk belum menjadi sebuah keseriusan dalam produk yang dihasilkan ini. Ini terbukti dengan adanya identitas produk dengan logo yang masih seadanya. Menggunakan Teknik tipografi dan monokrom. Sedangkan promosi berperan dalam menghasilkan penyampaian informasi yang baik pada konsumen akan manfaat atau kelebihan suatu produk, sehingga dapat mempengaruhi dalam benak konsumen dan akan menimbulkan minat untuk membeli produk tersebut (Silangsih \& Utami, 2018).

\section{Logogram dikutip dari} (Fermana, 2019) menurut Trinanda merupakan acuan untuk merancang sebuah visual logo dalam bentuk gambar 4. Bentuk logogram yang akan diambil yaitu berupa foto chef yang kemudian dibuat sketsa dari foto beruang tersebut dan dipindahkan kedalam aplikasi pengolah vektor pada komputer untuk mendapatkan hasil bentuk digital dan dilakukan penyederhanaan sesuai dengan karakter logo yang didapatkan dari rancangan kasar yang sudah penulis lakukan.

Tipografi merupakan salah satu seni untuk mengenal huruf (Fermana, 2019). Pemilihan tipografi yang sesuai untuk dijadikan logotype akan membantu dalam penjelasan bentuk dari logogram. Tipografi yang digunakan dalam logotype Kripik Tempe Mama Ghusla menggunakan nama font Abhaya Libre Regular dan Jingleberry. Tipografi ini disesuaikan dengan karakter logo, keinginan dari pemilik usaha Kripik Tempe Mama Ghusla dan disetujui oleh pembimbing.

Untuk membuat sebuah desain tentu tidak terlepas dari warna. Warna merupakan unsur paling penting dalam desain karena sebagai penanda emosional yang sangat kuat dan dapat mempengaruhi secara psikologi (Fermana, 2019). Logo yang dipilih berdasarkan tiga alternatif akan menggunakan biru sebagai warna background. Orange sebagai warna vektor dari Chef dan hijau sebagai warna dominan pada logo. Desain logo dibutuhkan untuk memperkenalkan produk ke masyarakat yang luas dan target pasarnya(Sijabat, Indah, Ramadhan, Ramadhani, \& Hasibuan, 2021). bahkan dapat dijadikan sebagai persepsi suatu produk serta pembanding antar satu produk dengan produk yang lain(Vidhiatama \& Nugroho, 2018).

Implementasi metode Bruce Archer pada perancangan Redesain logo Kripik Tempe Mama Ghusla dengan tiga tahapan atau fase dengan proses diuraikan sebagai berikut:

\section{Fase Analisis}

Pada perancangan Redesain logo pada tahapan ini masalah yang diperoleh dari observasi dan wawancara terhadap pemilik dari usaha yang berkaitan adalah kurangnya kreatifitas serta kurang menarik juga masih sederhana dari desain logo atau identitas visual dari produk Kripik Tempe Mama Ghusla. Data yang diperoleh pada tahapan ini adalah gambaran untuk dilakukannya perancangan Redesain logo yang kemudian di filter untuk dicari tahu makna dari gambaran konsep yang telah didapatkan. 


\section{Fase Kreatif}

Pada fase ini merupakan gabungan dari hasil analisis atau observasi yang digunakan untuk menyusun isi berserta makna dari Redesain logo yang akan dibuat. Pada tahapan ini dibuat sebuah mind mapping dari gambaran konsep logo yang akan dibuat.

\section{Fase Eksekutif}

Pada tahapan ini merupakan pengembangan dari ide yang didefinisikan atau dituangkan melalui solusi. Komunikasi yang menjadi bagian dari tujuan dari hasilnya. Tahapan ini memilih media yang sesuai untuk mengkomunikasikan hasil dari desain yang ada yang mana dalam hal ini adalah logo baru. Media atau aplikasi yang digunakan dalam perancangan Redesain logo ini adalah Canva. Logo ini yang kemudian menjadi sumber dari informasi atau sebagai media informasi untuk melakukan peningkatan dalam proses promosi produk.

\section{Logo}

\section{Deskripsi Logo}

Final logo atau identitas visual diatas dipilih berdasarkan persetujuan dari pemilik usaha Kripik Tempe Mama Ghusla yang telah disesuaikan dengan konsep juga teori yang digunakan dalam peracangan ini. Logo diatas dibagi atas logogram dan logotype. Pemilihan logo beserta warna yang ada pada logo telah disesuaikan dengan segementasi usia dan kata kunci yang sudah ditetapkan. Gambar chef dipilih karena memiliki salah satu karakter dari pemilik usaha Kripik Tempe Mama Ghusla yang ramah dan ceria.

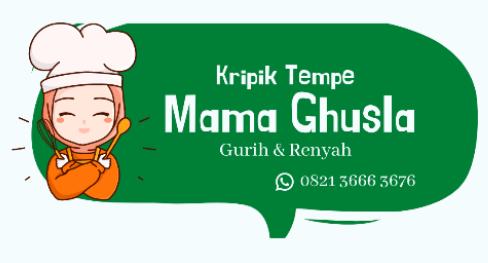

\section{Gambar 3. Final Logo Kripik Tempe Mama Ghusla}

Logotype difungsikan untuk menjelaskan produk yang dijual oleh Mama Ghusla. Dengan tipografi menggunakan Abhaya Libre Regular juga Jingleberry yang memiliki sifat unik, dinamis, dan tebal. Dalam logo ini juga dicantumkan contact person yang bisa dihubungi untuk konsumen yang mana ingin membuat pesanan terlebih dahulu secara online. Penggunaan simbol dengan berbagai elemen warna, huruf, kode yang dirangkai dalam bentuk logo menjadi sarana komunikasi yang banyak digunakan(Wahdaniah, Toni, \& Ritonga, 2020)

\section{Studi Tipografi Logotype}

$$
\text { Alternatif huruf yang }
$$

digunakan dalam redesain logo semestinya mencerminkan identitas Kripik Tempe Mama Ghusla sebagai produsen makanan ringan atau camilan. Dengan demikian font yang digunakan dalam Redesain logo ini sebagai pada tabel 1 .

Tabel 1. Tabel Font Desain Logo

\begin{tabular}{cc}
\hline Font & Contoh \\
\hline Abhaya Libre Regular & Gurih \& Renyah \\
Abhaya Libre Regular & 082136663676 \\
Jingleberry & $\begin{array}{c}\text { Kripik Tempe } \\
\text { Mama Ghusla }\end{array}$ \\
\hline
\end{tabular}




\section{Makna Warna}

Dalam Redesain logo ini warna yang digunakan adalah dominan warna dark cyan- lime green dan light grayish cyan. Dan juga warna icon vivid orange, very pale orange. Makna dari warna menurut psikologis (Febri, 2020) sebagai berikut

Tabel 2. Warna Redesain Logo

\begin{tabular}{ll}
\hline Warna & \multicolumn{1}{c}{ Makna } \\
\hline & Melambangkan \\
pengaruh yang & besar dan \\
semangat. & Melambangkan \\
pertumbuhan dan & harapan. \\
Warna ini sangat & mudah menarik \\
perhatian, efektif \\
dalam \\
mempromosikan \\
produk makanan \\
dan mainan. \\
Melambangkan \\
kegirangan, \\
seksualitas, Hasrat, \\
sensitifitas, dan \\
cinta. Sering \\
hubungkan dengan \\
hal-hal berbau \\
feminim.
\end{tabular}

\section{Konsep Pesan}

Konsep Verbal

Redesain logo Kripik Tempe

Mama Ghusla menggunakan pesan verbal yaitu nama usaha dan tagline. Nama usaha adalah Mama Ghusla dan dengan tagline "Gurih \& Renyah".

\section{Konsep Visual}

Produk Kripik Tempe Mama Ghusla merupakan produk olahan kedelai yang diproduksi sendiri yang dilakukan secara continue untuk memenuhi stok pada pasar. Sehingga data visual diperoleh dari jenis logogram. Dimana didalam icon chef
Wanita yang sederhana. Ini mencerminkan bahwa pemilik juga yang memproduksi Kripik Tempe ini adalah Mama Ghusla yang menampilkan kesan sederhana, fleksibel dan menarik terhadap produk.

\section{Proses Desain}

Pada tabel 3 diatas merupakan tabel proses desain 1 yang terdiri dari gambar 1 merupakan langkah pemilihan template pada aplikasi Canva untuk Redesain logo Kripik Tempe Mama Ghusla. pemilihan template ini berdasarkan dari mind mapping yang telah dibuat. Gambar 2 untuk mengedit template menjadi brand produk yang nantinya menjadi identitas visual pada produk Kripik Tempe Mama Ghusla. Pada gambar 2 menggunakan font Abhaya Libre Regular dan Jingleberry. Pada gambar 3 merupakan langkah untuk penambahan icon chef yang merupakan representasi atau visualisasi dari pemilik usaha yaitu Mama Ghusla. Dimana konsep ini mencerminkan Mama Ghusla yang sederhana dan ceria. Gambar 4 merupakan langkah untuk penambahan contact person untuk pemesanan produk Kripik Tempe Mama Ghusla melalui daring.

Pada tabel 4 proses desain 2 diatas pada gambar 5 merupakan langkah dimana penggantian warna latar belakang menjadi warna Light Grayish cyan. Dan pada langkah 6 merupakan penggantian warna latar belakang pada elemen menjadi warna dark cyan-lime green. Gambar 7 merupakan langkah penggantian warna font menjadi warna putih agar lebih terlihat cerah dan mudah terbaca oleh konsumen. Gambar 8 merupakan final desain Redesain logo Kripik Tempe Mama Ghusla. 
Tabel 3. Tabel Proses Desain 1

\section{Proses}

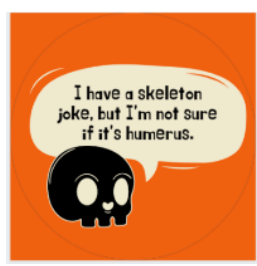

1. Pemilihan template pada aplikasi Canva untuk Redesain logo sesuai dengan konsep yang telah dibuat dari mind mapping.

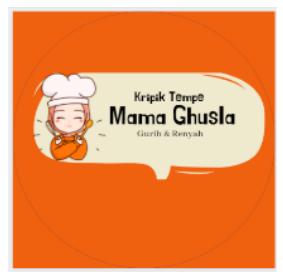

3. Penambahan icon chef sebagai visual dari pemilik usaha yaitu Mama Ghusla

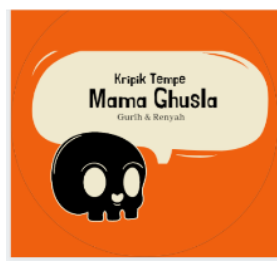

2. Penggantian teks sesuai dengan nama produk juga nama industri rumah tangga.

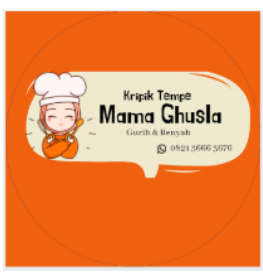

4. Penambangan contact person untuk narahubung pemesanan melalui online.
Tabel 4. Tabel Proses Desain 2

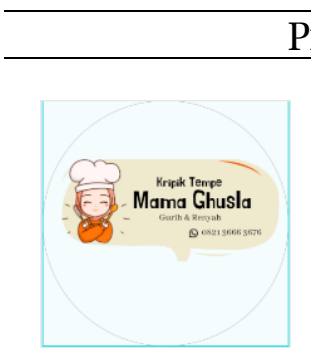

1. Penggantian background menjadi warna light grayish cyan.

\section{Proses}

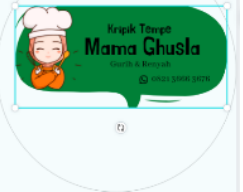

2. Penggantian warna latar belakang tipografi menjadi warna dark cyan- lime green.

\section{Perubahan} tata letak atau layout pada icon chef agar lebih proporsional.

\section{Penerapan Desain Logo pada Kemasan Produk}

Pada kemasan produk memiliki unsur visual dalam penerapannya. Penerapan Redesain logo pada Kripik Tempe Mama Ghusla sebagai identitas visual seperti tabel dibawah ini

Tabel 5. Penerapan desain logo pada Kemasan

\begin{tabular}{cc}
\hline Penerapan & $\begin{array}{c}\text { Penerapan Desain } \\
\text { pada kemasan } \\
\text { pada Lain Logo } \\
\text { Padaduk }\end{array}$ \\
\hline
\end{tabular}
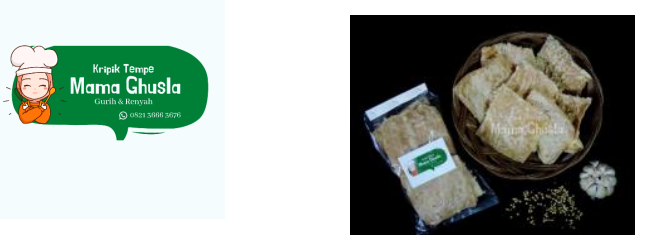

Desain poster sebagai media promosi dan penguatan identitas Produk Kripik Tempe Mama Ghusla

Visualiasasi desain poster atau brosur sebagai konten promosi pada media sosial seperti Facebook Ads sebagai penerapan dari digital marketing. Pada tabel dibawah ini menggunakan capaian penerapan desain dalam peningkatan promosi produk. 
Tabel 6. Konten Promosi pada Kripik Tempe Mama Ghusla

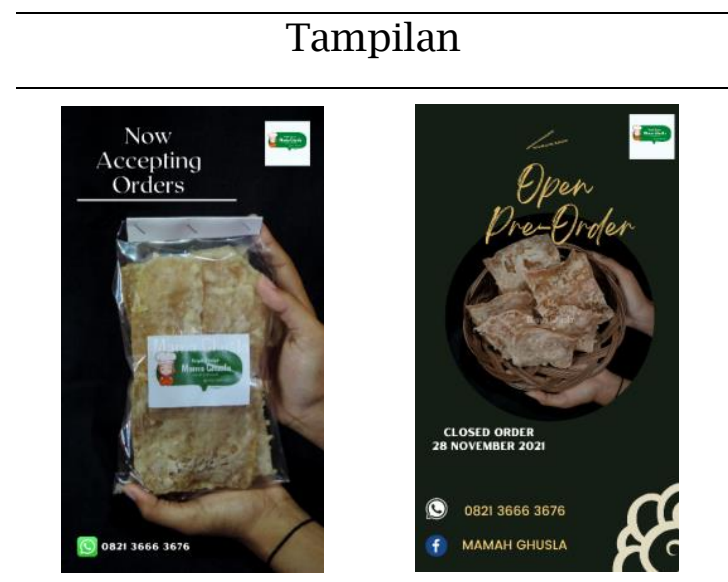

Setelah

menyelesaikan

perancangan Redesain logo dan memperkuat identitas visual melalui konten promosi produk yang berkualitas. Pengaplikasian logo sebagai penguat identitas visual dan media promosi pada Kripik Tempe Mama Ghusla dibuktikan dengan media pendukung yang meliputi media iklan (Facebook Ads), brosur atau poster. Implementasi identitas visual diterapkan pada konten promosi yang disesuaikan dengan konsep desain agar tercipta kesatuan desain yang mampu meningkatkan minat konsumen.

\section{Peningkatan dalam proses promosi produk Kripik Tempe Mama Ghusla}

Dari persoalan penelitian desain yang dihadapi oleh Industri Rumah Tangga Kripik Tempe Mama Ghusla di Desa Cikopeng Kecamatan Lumbir tentang Redesain logo yang sekaligus sebagai penguatan identitas visual dan peningkatan promosi produk bukanlah sebuah hal yang mudah. Hal ini dikarenakan didalam logo terutama diterapkan pada kemasan produk dan poster akan menggambarkan citra sebuah produk milik Mama Ghusla sekaligus sebagai upaya dalam membangun brand, maka sangat dengan wajar Industri Rumah Tangga ini harus memiliki strategi sendiri dalam menanamkan citra usaha agar lebih dikenal lagi di masyarakat.

Promosi merupakan suatu kegiatan yang mengkomunikasikan manfaat sebuah produk dan membujuk target konsumen untuk membeli produk tersebut. Indikator dari promosi terdiri dari salah satunya adalah informasi produk mendorong melakukan pembelian, promosi berperan dalam menghasilkan penyampaian informasi yang baik pada konsumen akan manfaat atau kelebihan suatu produk sehingga dapat mempengaruhi dalam benak konsumen akan menimbulkan minat untuk membeli produk tersebut (Silangsih \& Utami, 2018).

Pada umumnya promosi yang sudah dilakukan oleh peneliti sudah termasuk dalam kategori yang baik. Tayangan iklan sebagai indikator setelah dilakukannya branding dalam digital marketing yang dilakukan melalui Facebook Ads.

Meskipun dengan klik yang tidak cukup banyak dari iklan yang sudah ditayangkan pesanan yang masuk sebanyak 40 buah penjualan dalam satu minggu lebih banyak dibandingkan dengan sebelum dilakukannya promosi setelah dilakukannya Redesain logo. Ini berarti dengan promosi yang dilakukan informasi produk mendorong konsumen dalam melakukan pembelian.

\section{Pembahasan}

Berikut merupakan analisis data dari Industri Rumah Tangga Kripik Tempe Mama Ghusla:

\section{Strength (Kekuatan)}

Produk dibuat dan dikerjakan secara manual (self made) sehingga dikerjakan secara continue dan memiliki cita rasa yang stabil dari setiap produksi. Produk masih layak konsumsi hingga lebih dari sebulan 
dibandingkan dengan produk lainnya yang sejenis.

\section{Weakness (Kelemahan)}

Identitas visual yang dimiliki saat ini belum memiliki nilai estetika dan daya tarik untuk penguatan nilai identitas visual sehingga belum cukup menarik perhatian konsumen dalam melihat brand atau merk dari produk terkait. Tipografi logo yang kurang tegas dapat diperbarui dengan citra yang baru. Belum adanya sistem untuk mengelola hasil produksi dan sistem keuangan karna industri rumah tangga ini masih terbilang baru beroperasi kembali selama setahun kebelakang selama masa pandemic COVID-19.

\section{Opportunity (Peluang)}

Penggunaan logo baru akan memberikan kesan yang fresh terhadap identitas viusal produk daripada logo yang terdahulu. Meskipun logo atau identitas visual ini berganti akan tetap mudah dan cepat dikenali oleh konsumen atau pelangggan karna pergantian dari tipografi dengan penggunaan font yang lebih tegas dan jelas. Kripik Tempe dengan rasa original yang lebih renyah dan gurih juga ukuran Produk yang lebih besar dengan isi yang cukup banyak dengan harga 5.500 perbungkus sudah memiliki nilai tersendiri dibandingkan dengan produk pesaing lainnya yang sejenis.

\section{Threats (Ancaman)}

Perubahan logo atau identtitas visual yang terjadi memungkinkan membuat bingung konsumen atau pelanggan pada awalnya. Pesaing produk yang sejenis yang berasal dari kabupaten sekitar yang sudah beroperasi terlebih dahulu dibandingkan usaha Kripik Tempe Mama Ghusla atau yang baru merintis dengan usaha yang sejenis. Konsumen akan merasa bosan dengan varian rasa yang ada jika usaha Kripik Tempe Mama Ghusla tidak melakukan inovasi dengan varian rasa Kripik Tempe. Harga bahan baku yang digunakan bisa melejit tiba tiba sehingga akan mempengaruhi dalam jumlah produksi dan kenaikan harga.

Dari hasil analisis data diatas dapat disimpulkan bahwa sudah cukup banyak keunggulan yang diperoleh dalam penelitian ini untuk dilakukan perancangan ulang terhadap logo produk. Dengan digunakannya analisis SWOT ini dapat menimalisir ancaman dan kemungkinan buruk yang akan terjadi dan dapat digunakan sebagai bahan untuk membuat perancangan ulang logo Kripik Tempe Mama Ghusla.

\section{Konsep dan Desain Logo Baru}

Konsep awal yang akan digunakan dalam perancangan Redesain logo Kripik Tempe Mama Ghusla ini adalah bagaimana agar image yang diciptakan berdasarkan konsep yang diambil dari karakter pemilik usaha Kripik Tempe Mama Ghusla ini yaitu fresh dan ceria. Konsep ini merupakan konsep yang sangat sederhana tentunya agar mudah untuk dikenali dan diingat oleh konsumen yang kemudian akan menjadi pusat perhatian. Dengan dasar konsep ini akan dikembangkan dalam proses perancangan logo Kripik Tempe Mama Ghusla dengan campuran. Konsep Logo Kripik Tempe Mama Ghusla ini berdasarkan pada mind mapping penulis lakukan, terlihat pada gambar 4 . 


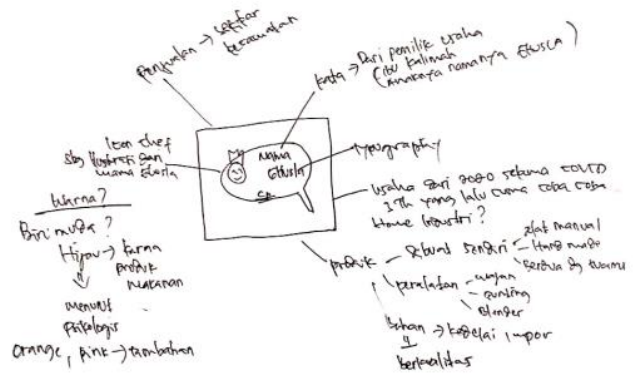

Gambar 4. Mind Mapping

\section{Simpulan}

Berdasarkan dari hasil penelitian dan pembahasan dalam Redesain logo Kripik Tempe Mama Ghusla, penulis menarik kesimpulan bahwa logo yang digunakan Kripik Tempe Mama Ghusla memiliki tampilan yang masih sangat sederhana. Maka dari itu penulis melakukan Branding Merk yang berupa merancang Redesain logo yang kemudian dijadikan sebagai penguatan dari identitas visual dan media utama untuk meningkatkan promosi produk Kripik Tempe Mama Ghusla sehingga produk lebih mudah dikenali dan menarik konsumen. Dalam mendesain sebuah logo yang bagus, harus memperlihatkan karateristik dari perusahaan tersebut baik itu mengenai filosofi, visi dan misi perusahaannya(Priani, 2018)

\section{Referensi}

Febri, R. (2020). Arti Warna Pada Logo.

Fermana, A. F. (2019). Redesign Logo Winnie Fruit Padang, 8(5), 55.

KBBI.Lektur.ID. (2021). Arti Tempe Kripik di Kamus Besar Bahasa Indonesia (KBBI).

Khairunnas, B. (2019). Redesign Logo Padek.Co, (September).

Namugenyi, C., Nimmagadda, L. S., \& Reiners, T. (2019). SWOT Analysis: A Theoretical Review.

Nismawati, F., Ade Lose Hermanto, Y., \& . P. (2020). Redesign Traditional Packaging of Jenang Sari Murni Tulungagung. KnE Social Sciences,
2020,

209-217.

https://doi.org/10.18502/kss.v4i1 2.7597

Priani, D. (2018). Perancangan Visual Branding Identity Mie Sop Kampung $\mathrm{Bu}$ Via Medan. PROPORSI: Jurnal Desain, Multimedia Dan Industri Kreatif, 4(1), 38. https://doi.org/10.22303/propors i.4.1.2018.38-49

Setiawan, T., \& Putro, F. H. (2021). Pemanfaatan Graphics Designer Software Canva Untuk Meningkatkan Kreatifitas Promosi Produk UMKM di Cepogo Boyolali. Intelektiva:Jurnal Ekonomi, Sosial \& Humaniora, 2(12), 53-56. Retrieved from https://www.jurnalintelektiva.com /index.php/jurnal/article/view/53 0

Sijabat, S., Indah, T. A., Ramadhan, F., Ramadhani, A., \& Hasibuan, S. H. (2021). Faktor-Faktor Yang Menentukan Keberhasilan Produk Melalui Desain Logo Pada Produk Og Home Care, 2(4), 195-199.

Silangsih, E., \& Utami, P. (2018). Pengaruh Marketing Mix Terhadap Minat Beli Konsumen Pada Usaha Mikro Kecil Dan Menengah (Umkm) Produk Olahan Makanan Ringan. Sosial Humaniora, 9, 144158.

https://doi.org/https://doi.org/10 .30997/jsh.v9i2.1382

Thabroni, G. (2019). Pengertian Desain (Lengkap) berdasarkan Pendapat Para Ahli.

Vidhiatama, Y., \& Nugroho, A. (2018). Persepsi Visual Logo Kereta Rel Listrik (Krl) Commuter Line Jabodetabek. Jurnal Dimensi DKV Seni Rupa Dan Desain, 3(2), 191. https://doi.org/10.25105/jdd.v3i2 .3604

Wahdaniah, I., Toni, A., \& Ritonga, R. (2020). Makna Logo Dinas Penerangan Tentara Nasional Indonesia Angkatan Laut. Warta ISKI, 3(01), 67-74. 
https://doi.org/10.25008/wartais ki.v3i01.57

Wahmuda, F., \& Hidayat, M. J. (2020). Redesain Logo Dan Media Promosi Sebagai Citra Produk Makanan Ringan Ukm Benok. ANDHARUPA: Jurnal Desain Komunikasi Visual \& Multimedia, 6(02), 147-159. https://doi.org/10.33633/andhar upa.v6i02.3307

Y., E. (2020). Suatu Pengantar Metode Dan Riset Desain Komunikasi Visual Dkv (I). Yogyakarta: PENERBIT DEEPUBLISH.

Zuhri, M. A., \& Febriyeni, E. (2020). Perancangan Redesain Logo Micow Padang, 4(1), 1-9. 